\title{
DESAIN KOMUNIKASI VISUAL SEBAGAI MEDIA INFORMASI PADA DITJEN APTIKA KEMENTERIAN KOMUNIKASI DAN INFORMATIKA JAKARTA
}

\author{
Po. Abas Sunarya ${ }^{1}$, Lisa Anisah ${ }^{2}$ \\ ${ }^{1,2}$ STMIK Raharja, Jl. Jendral Sudirman No. 40 Modern Cikokol - Tangerang \\ ${ }^{1}$ Dosen Magister Teknik Informatika STMIK Raharja, ${ }^{2}$ Mahasiswa Jurusan Teknik Informatika \\ STMIK Raharja Tangerang \\ E-mail: ${ }^{1}$ abas@ $@$ raharja.info, ${ }^{2}$ lisa@ raharja.info
}

\begin{abstract}
ABSTRAK
Ditengah generasi milenial yang ketat dan berteknologi canggih, setiap insan kreatif diharuskan untuk memiliki daya saing tinggi dan kualitas diri yang baik secara personal dan juga keahlian sehingga mampu dapat bersaing di dunia kerja nyata. Tidak hanya itu, perusahaan juga dituntut memiliki teknologi yang memadai dan pribadi yang berkualitas agar mampu bersaing di era globalisasi ini. Maka dari itu terciptalah project yang menjadikan salah satu program untuk mendapatkan pengalaman lebih mengaplikasikan dan mempraktekkan ke dalam sebuah karya nyata. Project ini menghasilkan desain dalam bentuk komunikasi visual seperti flyer, brosur, cover buku, dan logo yang menjadi informasi penting terkait dan diaplikasikan pada Kementerian Komunikasi dan Informatika Jakarta. Riset ini diharapkan pula menghadirkan sebuah komunikasi yang mempunyai visualisasi yang informatif, menghibur, serta edukatif serta dibingkai dalam perencanaan dan pengawasan di bawah payung hukum undang-undang yang berlaku.
\end{abstract}

Kata Kunci : Desain, Teknologi, Komunikasi Visual, perencanaan, pengawasan.

\section{ABSTRACT}

Amid the millenial generation of rigorous and technologically advanced, every creative person is required to have high competitiveness and personal qualities both personal and expertise so as to be able to compete in the real world of work. Not only that, the company is also required to have adequate technology and personal quality in order to compete in this era of globalization. Therefore created a project that makes one of the programs to gain experience more apply and practice into a real work. This project produces design in the form of visual communication such as flyer, brochure, book cover, and logo that become important information related and applied to the Ministry of Communication and Information Jakarta. This research is also expected to present a communication that has an informative, entertaining, educative and framed visualization in planning and supervision under the applicable law payments.

Key : Design, Technology, Visual Communication, planning, supervision.

\section{PENDAHULUAN}

Ditengah persaingan dunia yang ketat, setiap insan kreatif di haruskan untuk memiliki daya saing tinggi dan kualitas diri yang baik secara personal dan juga keahlian sehingga mampu menjadi yang terbaik di dunia kerja nyata. Tidak hanya itu, perusahaan juga dituntut memiliki teknologi yang memadai dan sumber daya manusia berkualitas agar mampu bertahan pada era globalisasi ini. Kementerian Komunikasi dan Informatika (Kementerian Kominfo) merupakan satu dari beberapa kementerian yang ada di Indonesia yang memiliki tugas mengatur segala urusan bidang komunikasi dan informatika di dalam pemerintahan untuk membantu Presiden dalam melancarkan pemerintahan negara.Direktorat Jendral Aplikasi Informatika bertugas melaksanakan perumusan dan pelaksanaan kebijakan di bidang penatakelolaan aplikasi informatika salah satu contohnya membuat berbagai aplikasi bermanfaat agar mudah digunakan oleh masyarakat. Pada saat ini teknologi informasi 
berkembang dengan cepat, satu yang paling di rasakan yaitu perkembangan internet, di mana dengan perkembangan internet kita menjadi mudah menghilangkan batasan jarak dan waktu, sehingga informasi dapat kita peroleh dimanapun dan kapanpun kita kehendaki. Salah satu media informasi yang tak lepas menggunakan internet adalah aplikasi berbasis desain komunikasi visual. Dengan desain banyak keuntungan yang didapatkan, contohnya kemudahan informasi yang diperoleh secara visual.

Desain komunikasi visual adalah aktifitas motorik yang melibatkan panca indera penglihatan dalam merangsang unsur-unsur visual sehingga terbentuk interaksi yang menekankan pada bahasa visual sebagai kekuatan utama.Persepsi-persepsi visual yang tercipta tidak hanya berdampak pada perilaku konsumtif saja, namun juga dapat membagikan dampak postitif. Komunikasi visual pun berkaitan dengan komunikasi kepada audiens melalui tanda yang dapat membentuki dan mempengaruhi perbedaan sebuah produk atau jasa. Elemen tersebut dapat menciptakan sebuah identitas dan citra, adapun komunikasi yang berkaitan dengan pemasaran dalam hal ini adalah periklanan, agar dapat berjalan secara efektif ada dua hal yang harus diperhatikan melalui tingkatan yaitu; mengkomunikasikan dan pelaksanaan tujuan pemasaran. Selain itu, keterampilan seperti ini dapat meliputi penjualan produk dan periklanan, menciptakan sebuah identitas secara visual untuk institusi, perusahaan dan produk. Dalam publikasi pesan dapat dilengkapi secara visual dengan lingkungan grafis dan desain informasi.

Berdasarkan wawancara yang dihasilkan dengan stakeholder Aptika, hingga sekarang sarana penunjang informasi yang digunakan berbentuk pengumuman berbasis Word of Mouth dan dinilai oleh pihak terkait bahwa informasi tersebut pada perusahaan masih sederhana dan belum update. Untuk itu kedepannya dari pihak kemen kominfo menghendaki bentuk media penunjang informasi berupa pengembangan media komunikasi visual tentang informasi seluruh aktifitas Direktorat Jendral Aplikasi Informatika pada Kementerian Komunikasi dan Informatika. Desain visual ini diharapkan dapat membantu dalam memberikan informasi serta promosi lebih baik.

\section{KAJIAN PUSTAKA}

Unit Pelaksana Teknis Bidang Pengembangan Sumber Daya Manusia dan Penelitian Komunikasi dan Informatika diklasifikasikan dalam 2 (dua) kelas terdiri atas

a. Balai Besar Pengembangan Sumber Daya Manusia dan Penelitian Komunikasi dan Informatika;

b. Balai Pengembangan Sumber Daya Manusia dan Penelitian Komunikasi dan Informatika.[1]

\section{Definisi Desain}

Desain adalah modal terbesar seorang desainer adalah konsep dan ide. Konsep adalah pengertian yang luas diperoleh melalui pengetahuan dan pengalaman yang dituangkan pada suatu mediaoutput baik kertas maupun elektronik.[2]

Desain grafis atau yang sekarang lebih dikenal dengan Desain Komunikasi Visual merupakan suatu bidang ilmu yang telah dikenal luas oleh masyarakat sejak tahun 60-an. Kehadirannya seiring dengan perkembangan industri di bidang yang butuh akan media promosi untuk mendukung informasi dan promosi produk. Media masa pun berkembang mulai dari yang cetak hingga digital yang pula ikut memacu perkembangan DKV.[3]

\section{Definisi Media}

Media adalah pengantar atau perantara yang digunakan oleh komunikator untuk menyampaikan sebuah pesan kepada komunikan dalam mencapai efek tertentu.[4]

\section{Definisi Informasi}

Informasi (information) dapat diartikan sebagai : "Informasi merupakan data yang diproses dalam bentuk yang mempunyai nilai nyata dan bermanfaat bagi penerimanya."[5]

\section{Definisi Project}


Project merupakan semua informasi berupa karya yang menarik seperti gambar, urutan klip, audio, narasi dan efek lain yang ditambahkan dalam storyboard atau timeline.[6]

\section{METODE PENELITIAN}

Metode kualitatif deskriptif lah yang digunakan dalam penelitian ini yang hasil penelitiannya mendeskripsikan tentang analisis, fakta-fakta dan keterangan dari berbagai macamsumber serta datadata pendukung lainnya. Obyek yang diteliti dalam adalah Obyek atau sasaran utama penelitian adalah Gambar Ilustrasi terkait komunikasi dan informatika.

Ada 3 metode yang dilakukan dalam penelitian ini, seperti pengumpulan data, merupakan observasi yang dilakukan dengan melihat langsung kepada suatu obyek yang diteliti yaitu konsep dan bentuk serta menjelaskan tentang gambar visualisasi ilustrasi yang menggunakan prinsip dan unsur desain. Melakukan observasi secara langsung dan melakukan wawancara langsung tanpa melalui media lain seperti facebook, website artwork. Dokumen tertulis, bukti berupa foto, arsip atau yang berkaitan dengan gambar merupakan berbagai sumber data lainnya. Untuk mendapat validitas data cara yang ditempuh adalah dengantriangulasi yang menggunakan cara observasi terhadap penelitian yaitu gambar ilustrasi dan sumber data utama merupakan dokumen tertulis yang berisikan hasil wawancara dengan narasumber, dokumentasi foto dan berbagai sumber tambahan yaitu berupa referensi buku yang berhubungan dengan kajian pustaka serta penelusuran media internet. Untuk meneliti lebih dalamtentang kebenaran penulisan penelitian, akan menempuh jalan informan review, yaitu suatu bentuk mengadakan wawancara yang dilakukan dengan disertai pembuatan gambar ilustrasi dan stakeholder yang bersangkutan.

\section{Literatur Review (Penelitian Sebelumnya)}

Literature review atau penelitian sebelumnya merupakan bentuk literatur tentang sebuah penemuan yang telah ditemukan oleh sumber sebelumnya (emprical fiding) dan berkaitan dengan topik penelitian. Literatur reviewbukan hanya berisi tentang hasil penelitian jurnal yang sesuai, namun berisi pula tentang tujuan penelitian, model yang digunakan, data dan hasil atau kesimpulan dari sebuah penelitian.Jika memungkinkan dan sangat dianjurkan untuk mencarikan jurnal atau hasil dari sebuah penelitian yang mendukung dan tidak dari jurnal yang direview dengan maksud peneliti akan mendapatkan gambaran permasalahan yang dihadapi lebih dalam dari sisi yang se-aliran pemikiran dan berbeda pemikiran.

Berdasarkan hasil penelitian, disimpulkan bahwa :

1. Penelitian yang dilakukan oleh Maimunah, dkk (2015) yang berjudul "Desain Grafis Untuk Media Promosi Pada Nusantara English Centre". Menjelaskan tentang komunikasi visual merupakan media, sebagai perantara yang digunakan untuk memberikan informasi kepada masyarakat mengenai bidang, karakteristik, visi misi sesuai dengan citra atau image dari lembaga pendidikan yang dijalankan. Dalam penelitian tersebut, maka terciptalah suatu kesan terhadap produk yang akan dipsarkan dengan kegiatan dan berbagai usaha dalam bisnis ataupun pemasaran. Desain dalam penelitian media promosi ini menghasilkan berbagai macam brosur, spanduk, poster dan flyer.[7]

2. Penelitian yang dilakukan oleh Nurazizah, dkk (2015) berjudul "Perancangan Media Komunikasi Visual Sebagai Penunjang Media Promosi Pada CV. Remaja Tailor". Penelitian ini membahas tentangbentukdesain yang beraneka ragam sesuai dengan kreatifitas yang dimiliki digolongkan menurut fungsidan tujuan diantaranyaadalah desain grafis, desain web, desain manufacturing, desain fashion, desain interior,desain arsitektur, dan lain-lain. Untuk memperkenalkan identitas CV. Gaya Remaja Tailor diperlukan sarana media informasi yang dapat memperkenalkan aset-aset perusahaan kepada konsumen dan relasi bisnis untuk menjalin kerjasama di bidang jasa layanan pembuatan pakaian jadi. Media promosi sangat dibutuhkan untuk eksistensi CV agar tetap menarik dimata masyarakat.. Gaya Remaja Tailor yang merupakan perusahaan yang berjalan dibidang jasa layanan pembuatan pakaian jadi.[8]

3. Penelitian yang dilakukan oleh Yulius (2016) yang berjudul "Peranan Desain Komunikasi Visual Sebagai Pendukung Media Promosi Kesehatan". Penelitian ini menganalisis tentang sejauh mana perkembangan promosi kesehatan yang selama ini beredar dimasyarakat terutama pada beberapa hal yang mencakup tentang komunikasi visual, strategi komunikasi dan strategi media yang digunakan. Manfaat dari perancangan ini adalah meningkatkan kualitas peran serta 
para perancang promosi kesehatan dalam membuat media promosi kesehatan yang tepat sasaran dan mampumenjangkau masyarakat agar masyarakat menjadi lebih menyadari tentang pentingnya merawat dan menjaga kesehatan.[9]

4. Penelitian yang pernah dilakukan oleh Rizal, dkk (2016)berjudul "Pola Literasi Visual Infographer Dalam Pembuatan Informasi Grafis". Penelitian ini menghasilkan pola literasi visual yang terbentuk dalam menafsirkan objek visual melalui membaca dan memahami konsep dasar desain. Dalam menciptakan infografis, desainer infographic memiliki alur kerja, yang brainstorming kegiatan, informasi dan pengumpulan data, penentuan konten, persiapan narasi, desain informasi visualisasi, dan publikasi infografis.[10]

5. Penelitianyang telah dilakukan atas nama Paramita dan Michael (2013) yang diberi judul "Perancangan Desain Komunikasi Visual Brand dan Media Promosi Dari Perusahaan Eazzy Dumpling". Dalam penelitian ini, memperkenalkan Eeazy Dumpling sebagai brand baru maka perlu membuat corporate identity sebagai patokan untuk keseluruhan brandnya menjadi konsisten. Sebagian besar dari media pendukung brand yang baru ini menggunakan sosial media agar dapat menjangkau kehidupan para anak muda.[11]

\section{HASIL DAN PEMBAHASAN}

\section{Software Yang Di Gunakan}

Pembuatan desain ini menggunakan softwareAdobe Illustrator CS6. Adobe Illustrator merupakan program aplikasi berbasis bitmap dan vektor yang beroperasi pada lingkungan Mac IOS dan Windows. Adobe Illustrator versi terbaru sekarang ini tentunya menawarkan fitur yang lebih canggih dan lengkap dari versi sebelumnya, yaitu Adobe Illustrator CS5.

\section{Proses Desain}

Desain komunikasi visualdiproses sebagai media informasi pada Ditjen Aptika Kementerian Komunikasi dan Informatika Jakarta dibuat dengan proses yang teratur agar mendapatkan sebuah kesempurnaan desain yang sangat diinginkan. Perencanaan secara teratur sebelum melakukan proses desain merupakan sebagian perkara yang sangat penting untuk dipertimbangkan. Pada tahapan dilaksanakannya sebuah pengembangan desain yang baik, terdapat 3 (tiga) tahap yang harus diketahui, yaitu : layout kasar yang merupakan sebuah tahapan perancangan desain yang hanya berwujud teks dan gambar, lalu layout komprehensif yaitu sebuah tahapan rancangan keseluruhan yang telah tersusun dengan sangat rapih dan baik, dan tahapan terahir yaitu final art work yang merupakan tahapan akhir dimana seluruh unsur telah tersusun secara teratur dan siap di print out serta dipublikasikan.

\section{Hasil Desain}

\section{1) Desain Cover}

Media desain cover adalah media komunikasi visual yang berisi pesan tentang isi dari buku terkait dengan warna senada dan komunikatif. Tampilan desain yang dibuat pada media ini berupa informasi mengenai programterkait Dijten Aptika Kemen Kominfo.

Ada beberapa cover yang dibuat pada Ditjen Aptika, seperti: 


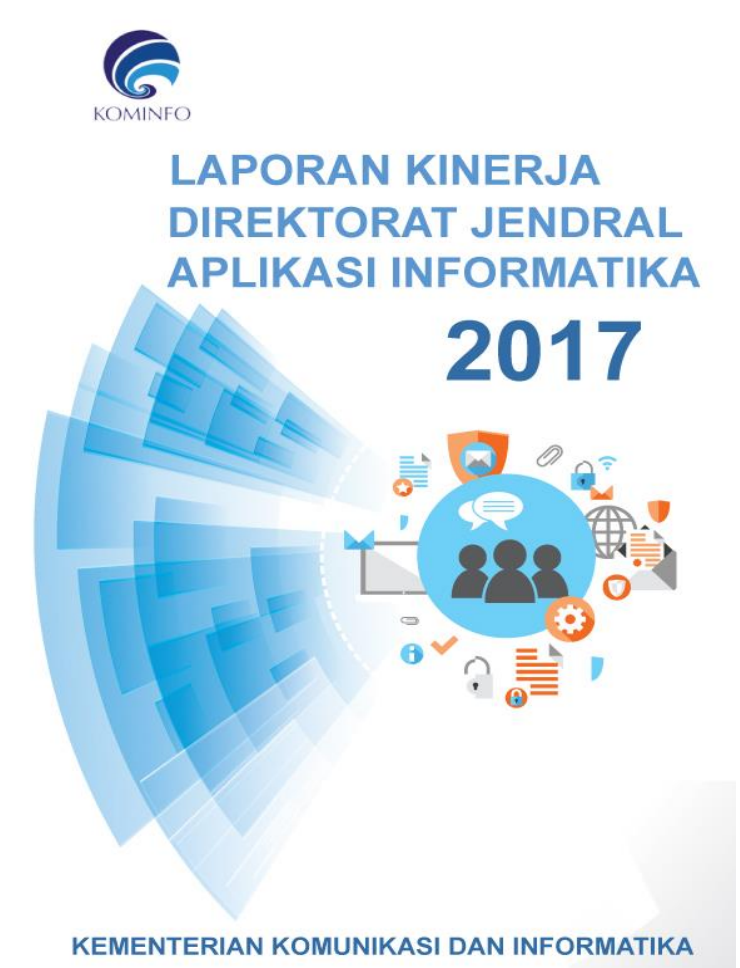

Gambar 1. Desain Cover Laporan Kinerja Aptika 2017

Laporan kinerja aptika berisikan tentang perbandingan tentang target kinerja dengan relasi masingmasing yang selanjutnya akan dianalisis lebih lanjut untuk diketahui apa kelebihan dan kekurangan dari sebuah kegiatan dan program yang diadakan Direktorat Jendral Aplikasi Informatika pada Kementerian Komunikasi dan Informatika jakarta.

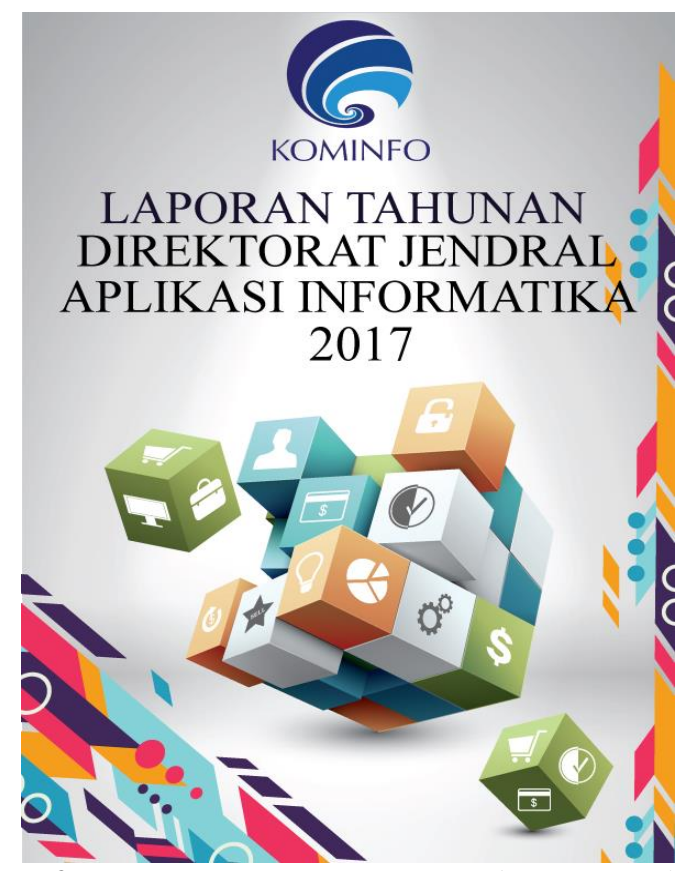

Gambar 2. Desain Cover Laporan Tahunan Aptika 2017.

Laporan Tahunan Aptika merupakan sebuah laporan yang mencakup laporan kegiatan selama setahun terakhir yang berisikan tentang perkembangan dan pencapaian yang telah berhasil atau gagal diraih oleh Direktorat Jendral Aplikasi Informatika. 


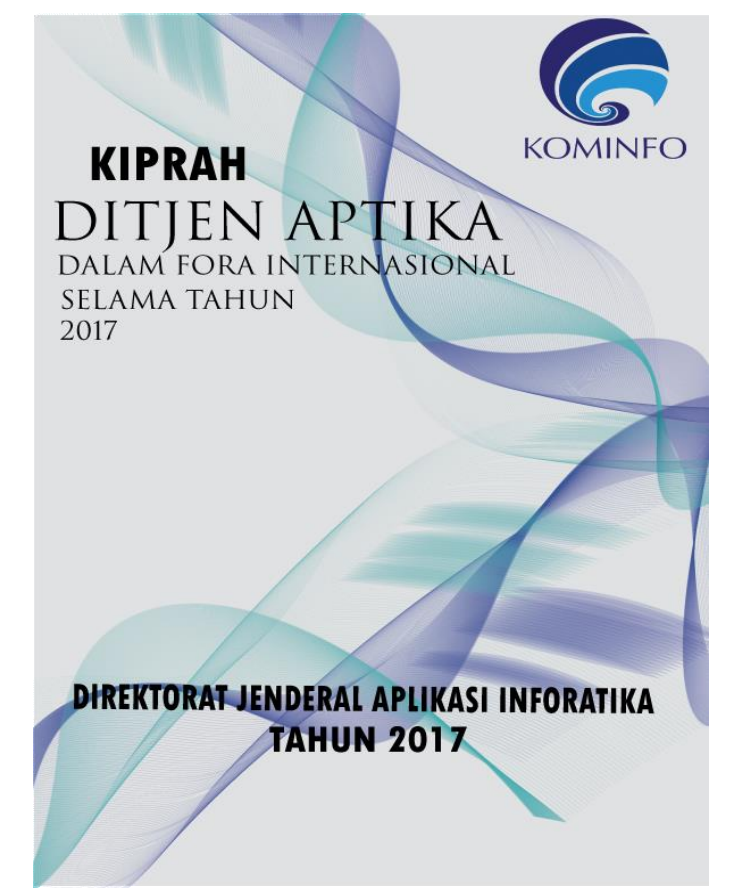

Gambar 3. Desain Cover Kiprah Aptika 2017.

Kiprah Aptika merupakan buku yang berisi laporan mensosialisasikan kegiatan dan program Ditjen Aptika dalam Fora Internasional selama satu tahun terakhir.

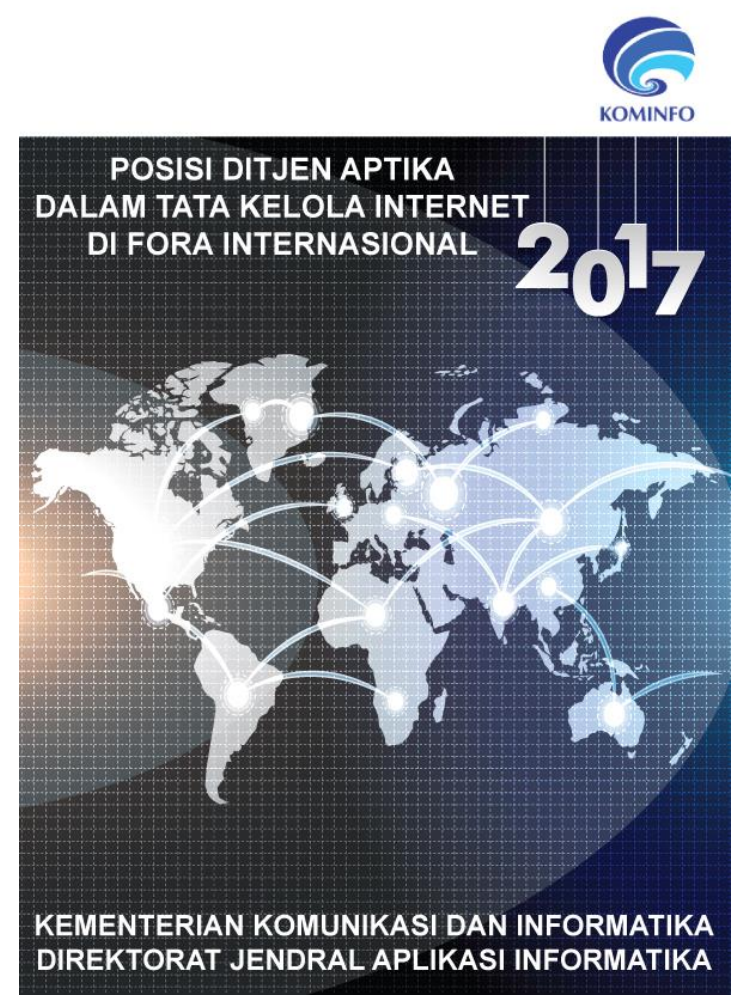

Gambar 4. Cover Disposisi Aptika 2017.

Disposisi Ditjen Aptika membahas tentang peran Aptika dalam tata kelola internet internasional dan akan terus bersuara tentang pentingnya posisi indonesia dalam tatakelola internet. 


\section{2) Desain Flyer}

Flyer adalah media komunikasi visual yang biasa dibuat dengan ukuran relatif kecil dan terdiri hanya satu lembar. Menyiarkannya dilakukan dengan dibagi-bagikan. Desain yang akan ditampilkan terdiri dari : Info program aplikasi yang dibuat oleh Aptika, dan info simposium yang akan diadakan oleh Aptika.

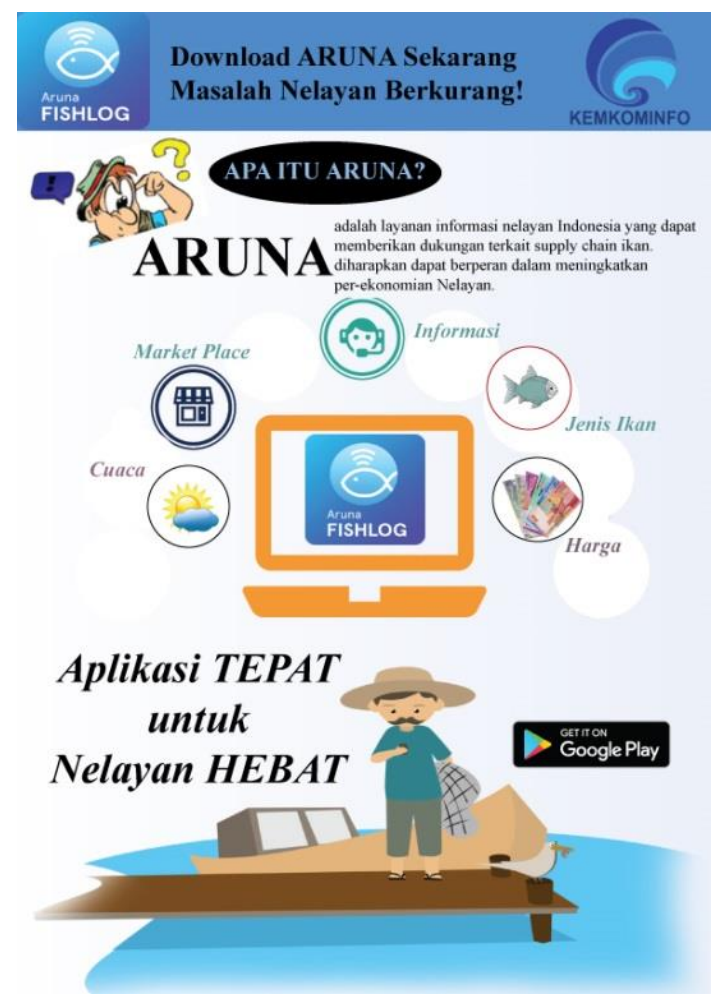

Gambar 5. Flyer aplikasi Aruna.

Aruna merupakan sebuah program yang baru diluncurkan oleh Aptika untuk memudahkan masyarakat terutama para nelayan agar dapat menjual hasil tangkapan laut mereka secara online dan secara tidak langsung dapat mengajarkan nelayan atau masyarakat lainnya agar melek akan teknologi yang sudah semakin canggih ini. Aplikasi Aruna dapat didownload secara gratis diplaystore ataupun appstore.

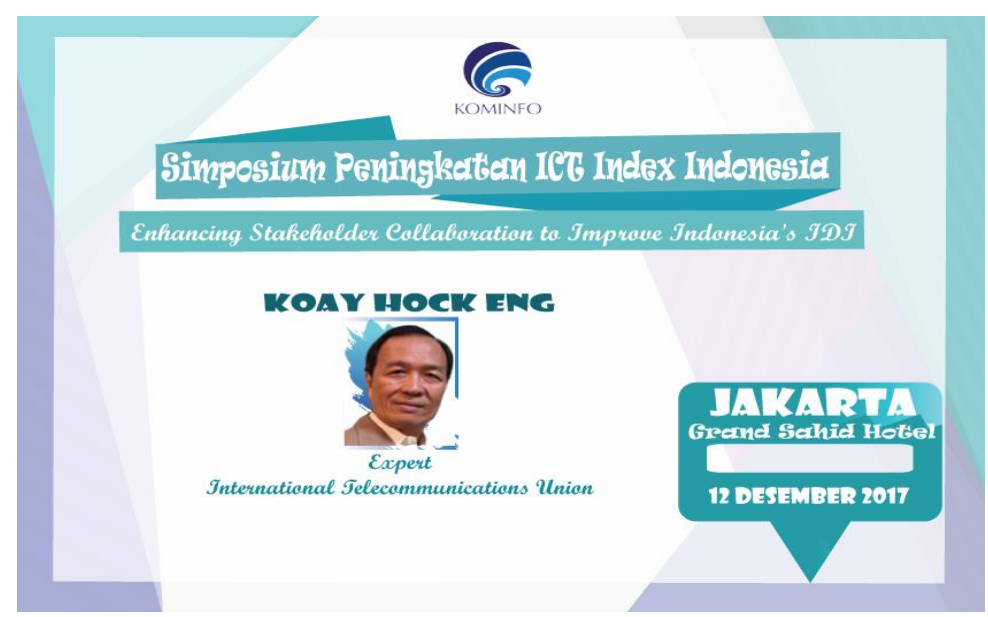

Gambar 6. Flyer untuk Simposium Ict Indonesia.

Simposium atau lebih dikenal dengan istilah seminar ICT Index Indonesia yang merupakan suatu kegiatan berbagi informasi teknologi kepada karyawan maupun masyarakat untuk hasil yang lebih baik. 


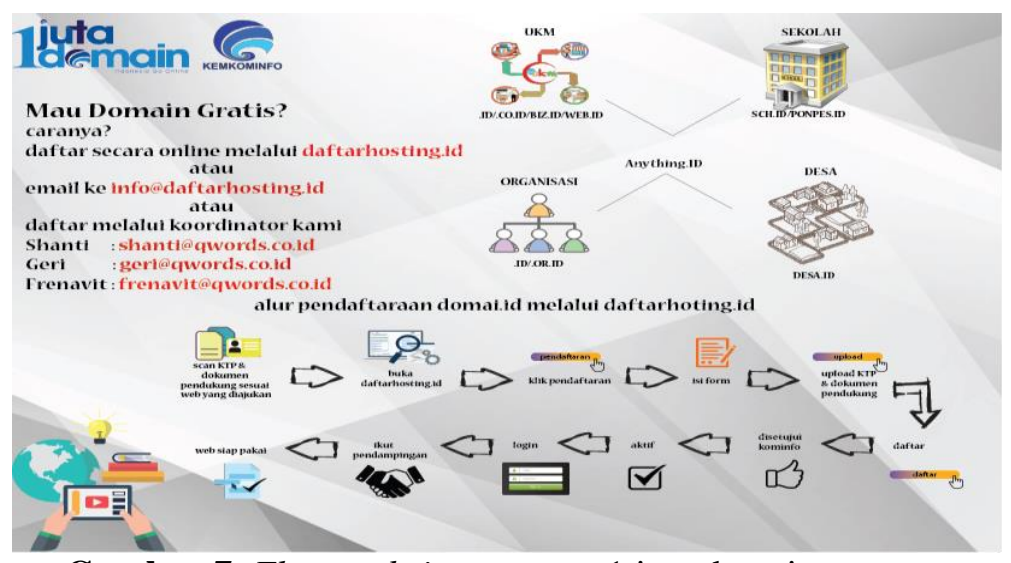

Gambar 7. Flyer website program 1 juta domain.

Program satu juta domain adalah sebuah program untuk mencapai konten positif dalam internet.

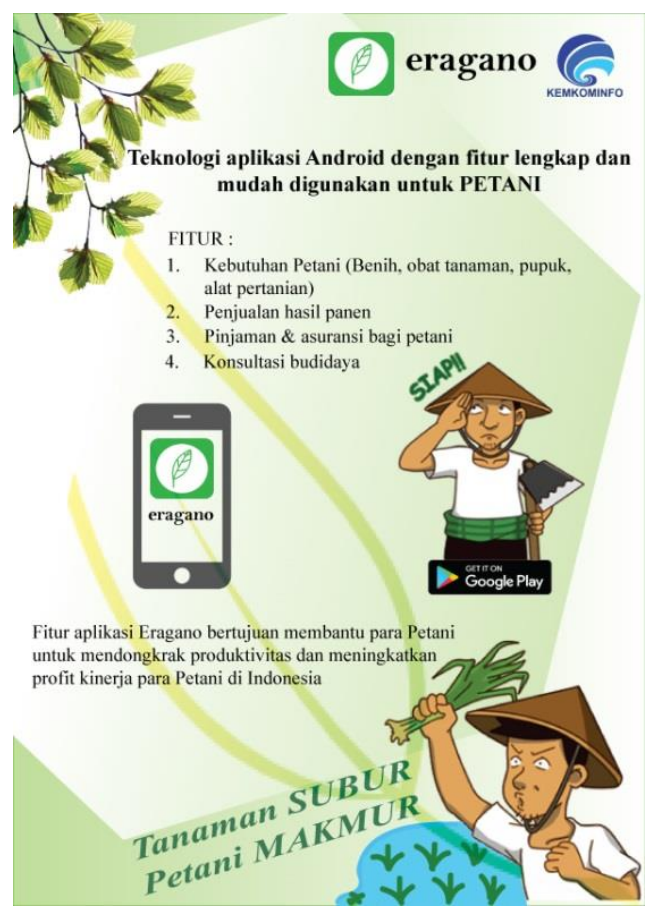

Gambar 8. Flyer aplikasi Eragano.

Eragano merupakan sebuah aplikasi marketplace untuk para petani. Aplikasi Eragano memudahkan para petani untuk bertransaksi via online. 
3) Desain Logo

Logo adalah sebuah media komunikasi berupa sketsa maupun gambar dengan artian tertentu dan dibuat agar mudah diingat sebagai simbol dari organisaasi, daerah, perusahaan lembaga, negara dan lainnya.

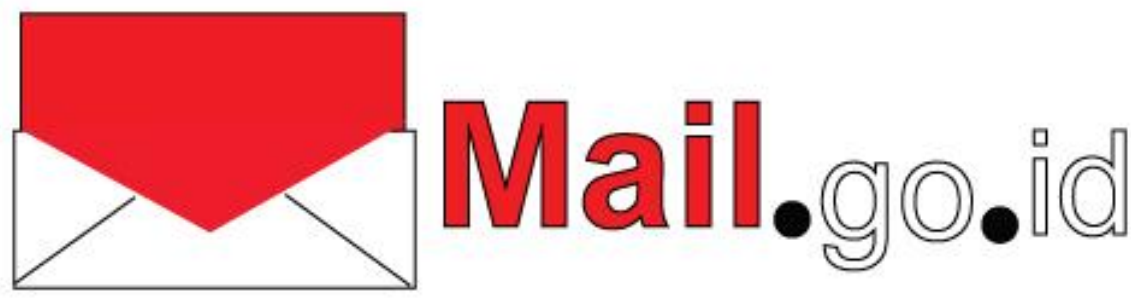

Gambar 9. Desain Logo Mailgoid.

Mailgoid merupakan sebuah website yang berisikan tentang data Pegawai Negeri Sipil. Mailgoid pun sedang proses membuat tanda tangan digital agar memudahkan para Pegawai Negeri Sipil mengirim surat secara elektronik tanpa harus bertemu satu dengan yang lainnya.

\section{KESIMPULAN}

Media pendukung informasi yang digunakan saat ini oleh Kementerian Komunikasi dan Informatika Jakarta belum sepenuhnya mewakili keseluruhan seperti yang diinginkan, sehingga masyarakat belum dapat memahami bagaimana program yang diluncurkan selama ini. Media yang yang baik seharusnya dapat memperhatikan aspek-aspek yang mampu memberikan ciri yang khas dari media tersebut, seperti aspek tampilan dan citra maupun unsur-unsur visual yang terstruktur, sehingga mampu mewakili atau menggambarkan image dari apa yang ingin dicapai oleh Kementerian Komunikasi dan Informatika sebagai salah satu lembaga pemeritahan yang mengatur segala program komunikasi.

Konsep perancangan desain komunikasi visual sebagai media informasi ini adalah tahapan proses kreasi yang mencakup berbagai mekanisme. Aspek kreatif, ekspresi, persepsi, karakter, produktif, inventif, inovasi, dan inspirasi serta emergentif yang keseluruhan hadir dalam konsep perancangan tertuju pada pencapaian nilai estetika. Panca indera dilibatkan pada pemilihan elemen desain yaitu ilustrasi, tipografi, warna, dan layout dalam proses kreatif. Proses kreatif yang mengarah pada dorongan seorang desainer untuk mencipta, menemukan sesuatu yang dianggap baru, dan melakukan perubahan-perubahan baik dalam skala kecil, sedang, maupun besar dalam desain komunikasi visual. Unsur-unsur tersebut yang nantinya ditangkap oleh audien sebagai pembawa pesan yang berkualitas dan mampu mengungkapkan bahkan mewakili dari sebuah identitas. Rasa sebagai kemampuan dalam menempatkan elemen desain pada dasarnya memberi kekuatan dalam mekanisme perancangan sebuah objek desain komunikasi visual.

\section{DAFTAR PUSTAKA}

[1] Peraturan Menteri Komunikasi Dan Informatika Republik Indonesia Nomor 19 Tahun 2017 Tentang Organisasi Dan Tata Kerja Unit Pelaksana Teknis Bidang Pengembangan Sumber Daya Manusia Dan Penelitian Komunikasi Dan Informatika

[2] Siswono, Achmad. 2013. Desain Grafis CorelDraw-Corel Photo Paint-Corel R.A.V.E. Jakarta : Lentera Ilmu Cendekia.

[3] Witari, Ni Nyoman Sri dan I Gusti Nyoman Widnyana. 2014. Desain Komunikasi Visual. Yogyakarta : Graha Ilmu.

[4] Kustiawan, Usep. 2016. Pengembangan Media Pembelajaran Anak Usia Dini. Malang : Gunung Samudera.

[5] Gerald, Davis. 2013. Organizations and Organizing Rational, Natural and Open System Perspectives. London and New York : Routledge Group. 
[6] Isroi. 2016. Trip and Triks Membuat Moviedan Foto Digital. Jakarta : Elex Media Kompuindo.

[7] Maimunah. Yusuf Hadi. Sartim. 2015. DesainGrafis Untuk Media Promosi Pada Nusantara English Centre. Bali : STMIK STIKOM Bali. Proceedings Konferensi Nasional Sistem dan Informatika : 437.

[8] Nurazizah. Arba Adnandi. Elvitasari Heriyanthi. Lely Suryani. dan Resti Avianingrum. Ladyca Anugrah. 2015. Perancangan Media Komunikasi Visual Sebagai Penunjang Media Promosi Pada CV. Remaja Tailor. Tangerang : Perguruan Tinggi Raharja. ISSN : 2302-3805. Journal Semnasteknomedia, Vol. 3 No.1 : 79.

[9] Yulius, Yoseph. 2016. Peranan Desain Komunikasi Visual Sebagai Pendukung Media Promosi Kesehatan. Palembang : Universitas Indo Global Mandiri. ISSN : 2502-8626. Journal Seni Desain dan Budaya,Vol. 1 No. $2: 42$.

[10] Rizal, Edwin. Nurul Miftah. danRully Anwar. 2016. Pola Literasi Visual Infographer Dalam Pembuatan Informasi Grafis. Journal Kajian Informasi, Vol. 4 No. $1: 87$.

[11] Paramita, Felicia dan Michael Nathaniel. 2013. Perancangan Desain Komunikasi Visual Brand dan Media Promosi Dari Perusahaan Eazzy Dumpling. Journal Visual Communication Design, Vol. 2 No. $3: 22$. 